\title{
Stability Monitoring of the Nitrification Process: Multivariate Statistical Analysis
}

\author{
Ewa Wąsik*, Krzysztof Chmielowski, Agnieszka Cupak, \\ Grzegorz Kaczor \\ University of Agriculture in Kraków, Department of Sanitary Engineering and Water Management, \\ Kraków, Poland
}

Received: 9 August 2017

Accepted: 24 September 2017

\begin{abstract}
The aim of this article is to define the possibilities of applying multivariate statistical analysis (PCA and control charts) in the monitoring of the effectiveness of biological nitrification in a wastewater treatment plant working for the municipality of Sanok. The difference in oxygen affinity between ammonium and nitrite oxidizers results in a bacteria competition between $A O M$ and NOM. A more stable nitrification process was obtained in reactor I for mean oxygen concentration of 1.13-2.05 $\mathrm{mgO}_{2} \cdot \mathrm{dm}^{-3}$. The lowest mean concentrations of ammonia nitrogen were obtained in the

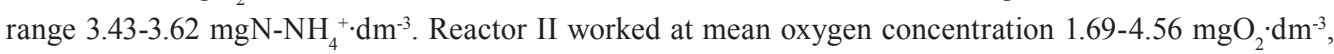
which caused lower stability in this study period. The mean concentration of ammonium nitrogen ranged from 4.06 to $9.08 \mathrm{mgN}-\mathrm{NH}_{4}^{+} \cdot \mathrm{dm}^{-3}$. April 2016 was considered the most stable period of work of nitrification reactors. In that month, in reactor I the upper specification limit USL was not exceeded. In reactor II the USL was exceeded only $10 \%$ of the time. The index of the process capacity $\mathrm{C}_{\mathrm{pk}}$ was higher for reactor I, and achieved a value of 1.71 . The process of nitrification in both reactors was qualified as stable when oxygen concentration was between 1 and $2 \mathrm{mgO} \cdot \mathrm{dm}^{-3}$.
\end{abstract}

Keywords: multivariate statistical analysis, control chart, wastewater treatment

\section{Introduction}

An effective and stable biological nitrification process requires appropriate selection of technological parameters different for each wastewater treatment plant due to its own operating conditions. The working conditions of the activated sludge should be properly selected in order to develop a large and diverse population of nitrifying bacteria. Growth rate of

*e-mail: ewa.wasik@urk.edu.pl the nitrifying bacteria mainly depends on substrate availability, i.e., $\mathrm{NH}_{4}^{+}$and $\mathrm{NO}_{2}^{-}$ions and concentrations of dissolved oxygen $D O$ [1].

The first stage of nitrification is carried out by the bacteria Nitrosomonas, Nitrosococcus, and Nitrosospira (ammonia-oxidizing bacteria, $A O B$ ) which oxidize ammonium ions via an intermediate hydroxylamine ( $A O B 1)$ to nitrite ions ( $A O B 2)$ [2-4]. $A O B$ are characterized by a long growth rate in comparison with heterotrophic bacteria, and sensitivity to toxic substances, i.e., nitrite ions. At the second stage of nitrification bacteria Nitrobacter, Nitrococcus, and Nitrospira (nitrite oxidizing bacteria, $N O B$ ) oxidize 
nitrite ions formed at the first stage to nitrate ions [2-4]. This stage depends on nitrite ions formed by $A O B$ and concentrations of dissolved oxygen.

At low oxygen concentrations $\left(0.3 \mathrm{mgO}_{2} \cdot \mathrm{dm}^{-3}\right), A O B 1$ are predominantly caused by the lowest oxygen affinity constant. At the oxygen concentrations within limits from 0.6 to $1.0 \mathrm{mgO}_{2} \cdot \mathrm{dm}^{-3}, A O B 2$ wins the competition because of its higher maximum growth rate [5-6]. At the $D O$ concentrations of $1.2-1.5 \mathrm{mgO}_{2} \cdot \mathrm{dm}^{-3}$ the difference in oxygen affinity between ammonium and nitrite oxidizers results in a competition between predominant $A O B$ and $N O B$ [7]. This caused the accumulation of toxic nitrite or the formation of toxic by-products such as $\mathrm{NO}$ and $\mathrm{N}_{2} \mathrm{O}$ $[2-3,8]$. Literature reports that nitrite oxidation could be inhibited below $4.0 \mathrm{mgO}_{2} \cdot \mathrm{dm}^{-3}$ [9]. For relatively high reactor oxygen concentrations and not too low influent ammonium concentrations, Volckle et al. [6] found the occurrence operating zones $A O B 1+N O B$ and $A O B 2+N O B$, resulting in nitrate formation.

The use of electricity for aeration in wastewater treatment plants (WWTP) accounts for $50-90 \%$ of total electricity consumption, which translates into up to $30 \%$ of total operating costs [10]. Excessive oxygen in the nitrification reactor usually results in worse sedimentation of the flocs in the sludge tank. It can also cause problems with the denitrification process, due to the oxygen returned to the non-air reactors with recirculation streams. Most WWTPs are operated at dissolved oxygen concentration in limits 2-2.5 $\mathrm{mgO} \cdot \mathrm{dm}^{-3}$ in order to ensure complete nitrification of ammonia to nitrate and the establishment of stable populations of bacteria $A O B$ and $N O B$. This value $2 \mathrm{mgO}_{2} \cdot \mathrm{dm}^{-3}$ is popular lower limit in reactors with bubble aeration [3]. The optimal dissolved oxygen concentration is related to an ammonium load. In order to term the optimal conditions for the nitrification process it should be checked if nitrification goes properly with lower oxygen concentrations of $1 \mathrm{mgO}_{2} \cdot \mathrm{dm}^{-3}$. This value defines the concentration at which the process of nitrification starts running with lower speed [11]. A reduction in oxygen concentration from 2.5 to $1 \mathrm{mgO} \cdot \mathrm{dm}^{-3}$ decreases the unnecessary consumption of electricity.

Information about oxygen concentration will help us better understand the biochemical processes by the WWTP operators and determine the optimal parameters for aeration. The amount of required oxygen should be tested in real conditions based on the measurements from online sensors of various nitrogen forms (ammonium, nitrites, nitrates). Online measurements and the application of a steering system and automation of SCADA (supervisory control and data acquisition) type allow for quicker detection of incorrect work or the failure in measurement instruments and sensors in a wastewater treatment plant, and consequently increase the technical reliability of the object [11]. To make steering and monitoring of technological processes more efficient, special software is applied and the management of vast installations is carried out with a computer in the scheduler's room. Apart from the system of information on the required service of the instruments (e.g., in the situation of failures), the course of technological processes should be enriched by the systems of its visualization with the possibility of their statistical analysis. For this purpose, specialist programs (i.e., ASIM, BioWin, and SIMBA) can be used. Their computer simulations describe the real course of technological processes [11]. Another easily accessible tool for the analysis and visualization of data in Microsoft Windows is Excel.

The observations of the studied process, i.e., according to the definition of the ordered sequence of changes, taking place subsequently in subsequent periods of times (e.g., hours, days, months), are often presented graphically using time series. One can single out the trend in cyclic or seasonal fluctuations due to the influence of various factors on the given phenomenon [12]. However, in such a big set of numbers, it is difficult to analyze and detect non-random changes (special disturbances) resulting from circumstances independent of the variability of the observed parameter of the process (affecting the process from outside). In quick detection of such disturbances, which can affect the process, and consequently, deteriorate the quality of the process, statistical process control (SPC) was applied. Usually it is carried out with Shewhart's control charts. This method was monitored and the regulation was proposed as graphical procedure, in which the main role is fulfilled by a properly prepared diagram (chart). Dr Walter Shewhart [13] explained that the process is regarded as controlled, when the experience from the past allows us to predict (at least approximately) the probability that the observed variables are within certain borders. The construction of a control chart is not very complicated, but it does require prior organization. For this purpose, it is necessary to find the frequency of the observation of variables (e.g., every 24 hours) and the number of observations (e.g., 24 times in 24 hours). Equally important is the instruments' precision of measurement and recording data obtained from them. The last step is a correct statistical analysis of the obtained results, compliant with the assumed technological assumptions.

In the control charts the technological process can be visualized in time in such a way that subsequent observations are graphically presented on the abscissa. In the case when numerical data are present in subgroups of the same number (k), the most popular chart to monitor variables for the mean value of the process $\left(\mathrm{X}_{\text {mean }}\right)$ was applied. While making the graph, the value of the observed characteristic of the variable (i.e., in this case the mean) was given on the ordinate. Additionally, apart from the central line (CL), a typical control chart contains two control limits: the lower control limit (LCL) and upper control limit (UCL). Control limits are established based on the variability inside the subgroup by the calculation of standard deviation. Usually single points corresponding to the 
values calculated from the variable are connected with lines. In cases when such a line exceeds the upper or lower control line or the line has an unusual appearance or some systematic layout, one can say that the process became deregulated [14-16].

The normal distribution represented by the Gauss curve is connected with the rule 3 sigma (standard deviation, $\sigma$ ) saying that $99.73 \%$ of observations are within the range $\mathrm{X} \pm 3 \cdot \sigma$. In case of the distribution of means from samples we used the concept of standard error, i.e., standard deviation means from samples. The error was estimated based on standard deviation calculated from a single sample divided by the square root from value $n$ (number) of this sample. In other words, standard deviation of the means is smaller than the standard deviation of the measurements by the square root from $n$. One should remember that the distribution value of means from k-element samples from the population is higher than the distribution of the whole population. Because the control limits have a smaller range, the control chart (apart from control limits) can get tolerance limits - the upper tolerance limit (UTL) and the lower tolerance limit (LTL). However, in this case, supervising the process, one should not only look at the fact that the means are within the limits of tolerance and, consequently, hastily make conclusions about a proper course of the process [17]. Due to the above, the analyzed data must be described by normal distribution. However, some deviations from the assumed normal distribution should not influence the reliability of the conclusions made by control charts [13], because they are based on practical experience [18].

Apart from control charts, other statistical tools can be applied in the supervision of the process. They would describe data grouped according to the defined criteria, e.g., correlation diagrams, regression charts, histograms. Using (apart from the above-mentioned statistical methods) traditional tools (i.e., sheets or control graphs) allow us to speak about the statistic steering the process, which according to Hamrol [19] is a broader concept than statistical control of the process [20]. Multivariate statistical techniques are used as environmentric tools both for water quality [21-26] and wastewater treatment efficiency [27-32].

Garcia-Alvarez et al. [33], making a model of detecting errors during the simulated work of the wastewater treatment plant, proposed the application of the MATALAB and SIMULINK programs. Janiak et al. [34] applied similar methods, i.e., Hotteling control charts $\mathrm{T}^{2}$ preceded by PCA, as the method of detecting measurement errors in the case of multidimensional relationships between the pollutants characterized by the work of the communal wastewater treatment plant in Wrocław. Akarupu et al. [27] used Minitab 17 as a technique of visual discrepancies of data collected for a water treatment plant.

This paper presents the assessment of the possibility of the application of PCA and control charts in the analysis and monitoring of biological treatment of wastewater by two variables: dissolved oxygen and ammonium nitrogen concentration. The variables present the work of nitrification reactors in the wastewater treatment plant in Trepcza in 2013-2016.

\section{Description of the Object}

A mechanical and biological wastewater treatment plant serves the agglomeration of Sanok. Its population equivalent (PE) is almost 76,000. The object is located in Trepcza [35]. At the beginning of 2013 the plant was designed for a daily capacity of up to $15,000 \mathrm{~m}^{3} / \mathrm{d}$. Purified wastewater is brought to the San River $(\mathrm{km}$ 275+400) (Fig. 1).

The technology of the wastewater treatment plant (opened in 1993) is based on the activated sludge method with the integrated removal of the compounds of carbon, nitrogen, and phosphorus [36]. Modernization of the wastewater treatment plant in Trepcza in 2013 meant the improvement of the biological part of the technological line of wastewater treatment (pre-denitrification reactor, de-phosphatation reactor, denitrification reactor, nitrification reactor, secondary decantation ponds) and providing the automatic steering system SCADA [37]. Due to the controlling and measuring instruments (online sensors including temperature, $\mathrm{pH}$, dissolved oxygen concentration, concentration of various nitrogen forms (ammonium, nitrates), and the concentration of phosphates), biological reactors are now monitored. Steering the activated sludge process is carried out in three variants: I - steering of $\mathrm{O}_{2}$, II - steering of $\mathrm{N}-\mathrm{NH}_{4}^{+}$, III - steering $\mathrm{N}^{-\mathrm{NO}_{3}}$, and $\mathrm{N}^{-} \mathrm{NH}_{4}^{+}$and internal recirculation. The SCADA system also provides visualization of the measurements in real time.

\section{Methods}

Source materials for the analysis were online measurements of physical and chemical indicators in two nitrification reactors collected in the database of the central computer of the wastewater treatment plant in Trepcza. The studies covered the period of four years from 2013 to 2016.

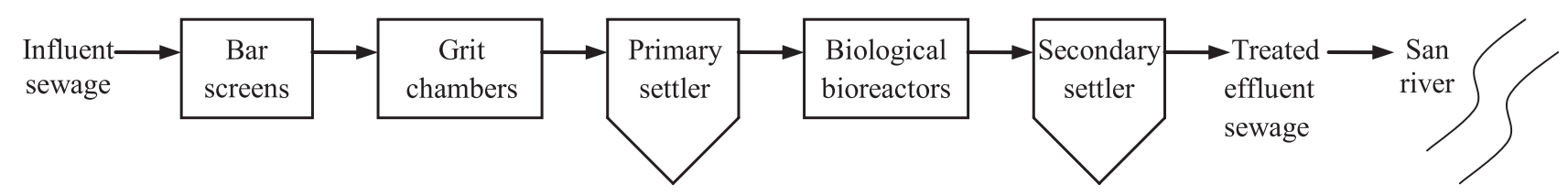

Fig. 1. Simplified technological scheme of the wastewater treatment plant in Trepcza. 
Due to the very large number of records (online measurements were made every hour) and their large dimension (individual records are defined by six variables), making a control chart was preceded by the choice of the controlled values, having a significant influence in the efficiency of the process. For this purpose, the value of parameters measured in the nitrification reactors were subdued by principal component analysis (PCA) [38]. The large amount of data made the authors select for analyses one springsummer month (April) and one autumn-winter month (October). The mean temperature in April is $8.1^{\circ} \mathrm{C}$, and in October is $9.1^{\circ} \mathrm{C}$ [39]. In 2013-2016 these months were characterized by the mean sum of precipitation $56.8 \mathrm{~mm}$ and $69.88 \mathrm{~mm}$, respectively [40]. These values turned out to be close to the mean of years 1881-2010, being $52.7 \mathrm{~mm}$ for April and $56.0 \mathrm{~mm}$ for October [41]. Input data for the graphic presentation of online measurements did not include the time immediately the object modernization of wastewater treatment plant (April 2013), because those time measurement instruments did not give the measurements of the value of pollutants getting to the object.

A subsequent stage was the calculation of basic statistics characterizing every selected variable (its subgroup), making Grubbs' test of the deviating values and the definition in the analyzed means of the variables in the normal distribution. To carry out this analysis two main parameters selecting the PCA method were taken into account. They show the work of nitrification reactors I and II, i.e., the concentration of dissolved oxygen and the concentration of ammonium nitrogen [38].

The analysed set consisted of $30 \div 31$ measurement days (24 hours a day) and for 7 months duration 4 years (three times April and Four times October), i.e. on average 214 records defined by 2 selected variables. Arithmetic mean, median, minimum, maximum, range, standard deviation, standard error, and variability coefficient were calculated.

The procedure of making a control chart for the mean value of the process $\mathrm{X}_{\text {mean }}$ involved first of all marking the central line $\mathrm{CL}$, which was the arithmetic mean of daily means of given parameter measurements (e.g., concentration of $\mathrm{N}^{-\mathrm{NH}_{4}}{ }_{4}^{+}$). The upper (UCL) and lower control limit (LCL) was calculated from the following relationships:

$$
\begin{aligned}
& \left.\mathrm{UCL}=\mathrm{X}_{\text {mean }}+3 \sigma \sqrt{\mathrm{n}}\right) \\
& \left.\mathrm{UCL}=\mathrm{X}_{\text {mean }}-3 \sigma \sqrt{\mathrm{n}}\right)
\end{aligned}
$$

...where $\mathrm{X}_{\text {mean }}$ is mean value, $\sigma$ is standard deviation, and $\mathrm{n}$ is sample size. After marking these limits in the form of horizontal lines, the measurement results of the examined characteristic of the variable were brought to the chart in the form of the daily mean of their value.
The subsequent step was the analysis of the chart to show possible symptoms indicating special disturbances, meaning that the process was de-regulated. To simplify the analysis, one of seven situations, when the process is not regulated statistically (ISO 7870-2:2013), was taken into account. Thus it was investigated if all the points are between control lines (stabilized process), or if they go beyond the limits of tolerance and specification (unstable process). In 7 months when control was carried out, the number of situations was noted when one or more points were beyond control lines.

For the chart presenting the content of dissolved oxygen in reactors I and II, the lower tolerance limit LTL equalled $1.0 \mathrm{mgO}_{2} \cdot \mathrm{dm}^{-3}$.

In case of the analysis of the concentrations $\mathrm{N}_{-} \mathrm{NH}_{4}^{+}$ in both reactors in April and October, based on their mean value of this period, LSL and USL for ammonium nitrogen were calculated from the following formula:

$$
\begin{aligned}
& \left.\mathrm{USL}=\mathrm{X}_{\text {meanA/O }}+3 \sigma \sqrt{\mathrm{n}}\right) \\
& \left.\mathrm{USL}=\mathrm{X}_{\text {meanA/O }}-3 \sigma \sqrt{\mathrm{n}}\right)
\end{aligned}
$$

...where $\mathrm{X}_{\text {meanA/O}}$ is mean value in reactors I and II for April (A) or October (O), 2013-2016; $\sigma$ is standard deviation; and $\mathrm{n}$ is sample size.

In the case of reactor I the following values of specification limits were established: for April $\mathrm{USL}_{\mathrm{AI}}=5.14 \mathrm{mg} \cdot \mathrm{dm}^{-3}, \mathrm{LSL}_{\mathrm{AI}}=2.61 \mathrm{mg} \cdot \mathrm{dm}^{-3}$, for October $\mathrm{USL}_{\mathrm{OI}}=4.31 \mathrm{mg} \cdot \mathrm{dm}^{-3}$, and $\mathrm{LSL}_{\mathrm{OI}}=2.25 \mathrm{mg} \cdot \mathrm{dm}^{-3}$. For reactor II these limits had higher values: $\mathrm{USL}_{\text {AII }}$ $=6.82 \mathrm{mg} \cdot \mathrm{dm}^{-3}, \mathrm{LSL}_{\mathrm{AII}}=3.94 \mathrm{mg} \cdot \mathrm{dm}^{-3}, \mathrm{USL}_{\mathrm{OII}}=$ $7.58 \mathrm{mg} \cdot \mathrm{dm}^{-3}$, and $\mathrm{LSL}_{\mathrm{OII}}=4.54 \mathrm{mg} \cdot \mathrm{dm}^{-3}$, respectively. Calculating monthly percentages of the incidents of exceeding the ammonium nitrogen concentrations in both reactors, first of all the points beyond the upper control limits were taken into account.

The potential capability index $\left(\mathrm{C}_{\mathrm{p}}\right)$ to fulfill specific requirements defined by the USL (upper specification limit) and LSL (lower specification limit) was calculated from the following relationship:

$$
\mathrm{C}_{\mathrm{p}}=\frac{\mathrm{USL}-\mathrm{LSL}}{6 \sigma}
$$

...where USL is upper specification limit, LSL is lower specification limit, and $\sigma$ is standard deviation.

When the range of the process control limits (UCL-LCL) equals the specification range (USLLSL), $C_{p}=1$. This is the capacity for which the fraction of discrepancy is $0.27 \%$ [18, 42]. Otherwise, when $(\mathrm{UCL}-\mathrm{LCL}) \neq$ (USL-LSL), based on the index of the capacity of the process meeting the requirements of the specification limits, it can be stated if the increase or decrease of the discrepancy fraction occurred. For the most commonly accepted capacity index $\mathrm{C}_{\mathrm{p}}=1.33$, the discrepancy fraction plummets to the value of $0.0063 \%$ [42]. When the process is not centred, i.e., when the 
mean of the process is different than the middle of the specification range, additionally the index of the process capacity $\mathrm{C}_{\mathrm{pk}}$ is calculated as the smaller of the two values according to formulas 6 and 7 [42]:

$$
\begin{aligned}
& \mathrm{C}_{\mathrm{pk}}=\frac{\mathrm{USL}-\mathrm{X}_{\text {mean }}}{3 \sigma} \\
& \mathrm{C}_{\mathrm{pk}}=\frac{\mathrm{X}_{\text {mean }}-\mathrm{LSL}}{3 \sigma}
\end{aligned}
$$

...where USL is upper specification limit, LSL is lower specification limit, $\mathrm{X}_{\text {mean }}$ is mean value, and $\sigma$ is standard deviation.

Statistical analysis was carried out with Excel 2010.

\section{Results and Discussion}

The primary dataset was preliminarily processed in terms of main components [38]. The analysis showed that three main components explained variability of original data in the range from $74.3 \%$ to $82.6 \%$. The first main component, in highest degree connected with the variability of dissolved oxygen concentration and ammonium nitrogen concentration in the nitrification reactors, explained between $38.8 \%$ and $45.0 \%$ of the variability of the contained primary variables. Thus, in order to carry out the analysis of the work of nitrification reactors in the wastewater treatment plant in Trepcza, these two indicators were selected.

Statistical analysis of source data for April and October in the time of studies from 2013 until 2016 were presented in Tables 1 and 2, respectively. Comparing the operating parameters of both reactors, it can be concluded that in most of the reported months reactor I was characterized by a higher coefficient of the oxygen variability and a lower mean oxygen concentration (1.14 to $3.45 \mathrm{mgO} \cdot \mathrm{dm}^{-3}$ ). By analyzing the nitrification process in reactor II, it was found that the mean oxygen concentration varied from 1.69 to $4.56 \mathrm{mgO}_{2} \cdot \mathrm{dm}^{-3}$. The highest mean values of ammonium nitrogen in nitrification reactor I in April 2014 and in nitrification reactor II in April 2015 were observed. Close to zero minimal values of ammonium nitrogen in both reactors were observed in October 2013 and April 2014. These periods were also characterized by the highest coefficients of variability $\mathrm{N}_{-} \mathrm{NH}_{4}^{+}$. Authors in previous analyzes [39] showed that in reactor II the concentrations of dissolved oxygen, ammonium nitrogen, and nitrate nitrogen were most correlated. However, in reactor I they observed only the relationship between the concentrations of dissolved oxygen and ammonia nitrogen. Differences in oxygen concentration in the reactors caused an increase in another population of nitrification microorganisms [38].

When analyzing data from 7 months, daily mean values of ammonium nitrogen concentration calculated for both reactors were defined by normal distribution.

\begin{tabular}{|c|c|c|c|c|c|c|c|c|c|}
\hline \multirow{4}{*}{ 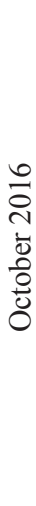 } & $\sum_{i}^{+}=$ & $\begin{array}{l}\stackrel{0}{\circ} \\
\dot{1}\end{array}$ & $\vec{\sim}$ & $\stackrel{\infty}{=}$ & $\begin{array}{l} \pm \\
\dot{r}\end{array}$ & $\begin{array}{l}\infty \\
\stackrel{0}{0} \\
\text { i }\end{array}$ & $\stackrel{\infty}{n}$ & $\begin{array}{l}\text { in } \\
\text { in }\end{array}$ & $\stackrel{\overbrace{}}{0}$ \\
\hline & $\sum_{i}^{+}-$ & $\stackrel{\Re}{\stackrel{m}{r}}$ & ণ্ & $\stackrel{0}{=}$ & $\stackrel{n}{r}$ & ñ & 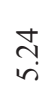 & $\begin{array}{l}\underset{+}{+} \\
\text { to }\end{array}$ & กี \\
\hline & $\begin{array}{l}\bar{\Xi} \\
\infty \\
\text { స్ } \\
0\end{array}$ & $\stackrel{\overbrace{}}{n}$ & $\frac{n}{0}$ & $\begin{array}{l}0 \\
0 \\
0\end{array}$ & $\underset{\dot{r}}{\Delta}$ & $\stackrel{n}{\stackrel{n}{\sim}}$ & $\stackrel{n}{n}$ & $\stackrel{\circ}{\stackrel{0}{m}}$ & $\begin{array}{l}\text { ஸे } \\
\text { o }\end{array}$ \\
\hline & $\begin{array}{l}\tilde{5} \\
\infty \\
\vec{\delta}-1\end{array}$ & $\underset{ }{\stackrel{+}{*}}$ & ல̂. & ๗ి? & $\widehat{\sigma}$ & $\bar{\sigma}$ & 華 & $\stackrel{n}{n}$ & ָ̃ \\
\hline \multirow{4}{*}{$\begin{array}{l}n \\
0 \\
0 \\
\dot{0} \\
0 \\
0 \\
\dot{0} \\
0\end{array}$} & $\sum_{i}^{+} \mathbb{z}_{i}^{+}=$ & $\underset{+}{\stackrel{\circ}{+}}$ & $\stackrel{n}{\tilde{c}}$ & $\stackrel{\infty}{\sim}$ & $\begin{array}{c}\infty \\
\dot{\infty}\end{array}$ & ભે & $\underset{0}{0}$ & $\begin{array}{l}\infty \\
\stackrel{\infty}{+}\end{array}$ & $\stackrel{+}{m}$ \\
\hline & $\sum_{i}^{+}-$ & 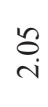 & $\stackrel{\overbrace{}}{\tilde{o}}$ & 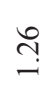 & $\stackrel{\infty}{-}$ & $\stackrel{+}{+}$ & $\begin{array}{l}\underset{+}{+} \\
\dot{+}\end{array}$ & $\stackrel{\vartheta}{\ominus}$ & $\underset{\dot{0}}{\dot{0}}$ \\
\hline & 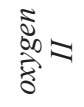 & $\begin{array}{l}\infty \\
\text { ָ } \\
\end{array}$ & $\frac{1}{\stackrel{0}{0}}$ & in & $\begin{array}{l}n \\
\infty \\
i\end{array}$ & $\underset{ت}{ت}$ & $\stackrel{\infty}{\circ}$ & $\hat{n}$ & $\stackrel{\overbrace{}}{0}$ \\
\hline & $\begin{array}{l}\overline{5} \\
\infty \\
\vec{\jmath}_{0}-1\end{array}$ & 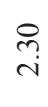 & $\frac{n}{0}$ & $\stackrel{\infty}{\infty}$ & $\begin{array}{l}\mathbb{O} \\
\stackrel{i}{N}\end{array}$ & ๓े & $\stackrel{\infty}{\underset{f}{+}}$ & $\stackrel{8}{\stackrel{\leftrightarrow}{i}}$ & $\begin{array}{l}0 \\
\text { ?’ }\end{array}$ \\
\hline \multirow{4}{*}{$\begin{array}{l}\text { J } \\
\text { ते } \\
\dot{8} \\
\stackrel{0}{0} \\
\stackrel{0}{0}\end{array}$} & $\sum_{z}^{+} \sum_{z}^{+}=$ & $\underset{0}{+}$ & 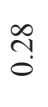 & $\tilde{n}$ & กֶ & $\stackrel{\infty}{\infty}$ & $\vec{\infty}$ & $\stackrel{n}{0}$ & $\begin{array}{l}\text { N̦ } \\
\stackrel{0}{0}\end{array}$ \\
\hline & $\sum_{\sum_{1}^{+}}^{+}-$ & 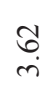 & 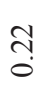 & $\stackrel{n}{n}$ & $\begin{array}{l}\text { ָे } \\
\text { rn }\end{array}$ & $\underset{\sigma}{\sigma}$ & $\underset{0}{\infty}$ & $\frac{\infty}{i}$ & $\stackrel{n}{\tilde{c}}$ \\
\hline & $\begin{array}{l}\overline{5} \\
\frac{\infty}{\delta} \\
\frac{5}{5}\end{array}$ & $\stackrel{\text { ọ }}{\text {. }}$ & $\frac{1}{0}$ & مু & $\stackrel{\infty}{\sim}$ & $\stackrel{\infty}{\stackrel{0}{0}}$ & $\begin{array}{l}8 \\
\dot{r}\end{array}$ & $\begin{array}{l}\infty \\
\infty \\
i\end{array}$ & 苞 \\
\hline & $\begin{array}{l}\tilde{5} \\
\infty \\
\text { हై } \\
0\end{array}$ & $\stackrel{\Xi}{\leftrightarrows}$ & $\stackrel{\sim}{\stackrel{0}{0}}$ & $\underset{0}{0}$ & $\stackrel{?}{\stackrel{0}{0}}$ & $\tilde{n}$ & $\begin{array}{l}\infty \\
\infty \\
i\end{array}$ & ָे & ñ \\
\hline \multirow{4}{*}{ 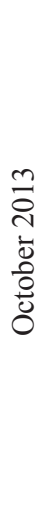 } & $\sum_{i}^{+}=$ & $\stackrel{\infty}{\circ}$ & $\stackrel{\infty}{\stackrel{\sim}{\longrightarrow}}$ & $\stackrel{\simeq}{\simeq}$ & \begin{tabular}{l}
$\circ$ \\
\hdashline
\end{tabular} & $\underset{0}{0}$ & $\frac{\vec{D}}{\dot{m}}$ & $\begin{array}{l}n \\
\text { ?n } \\
\text { n}\end{array}$ & 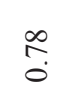 \\
\hline & $\sum_{i}^{+}-$ & $\begin{array}{l}\widetilde{\sigma} \\
\stackrel{+}{*}\end{array}$ & $\stackrel{m}{\stackrel{0}{0}}$ & $\stackrel{\leftrightarrow}{\stackrel{n}{+}}$ & $\begin{array}{l}\stackrel{+}{r} \\
\stackrel{2}{n}\end{array}$ & 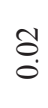 & $\begin{array}{l}\vec{\sim} \\
\dot{I}\end{array}$ & $\stackrel{\vartheta}{\stackrel{+}{ \pm}}$ & $\stackrel{\overrightarrow{0}}{-}$ \\
\hline & $\begin{array}{l}\overline{5} \\
\infty \\
\overrightarrow{3} \\
0\end{array}$ & in & $\begin{array}{l}\infty \\
\text { ? } \\
0\end{array}$ & $\stackrel{\circ}{i}$ & $\stackrel{n}{-}$ & $\stackrel{\cong}{\rightleftarrows}$ & $\stackrel{g}{\circ}$ & $\begin{array}{l}\circ \\
\stackrel{2}{1} \\
\text { in }\end{array}$ & $\begin{array}{l}\infty \\
\infty \\
0\end{array}$ \\
\hline & $\begin{array}{l}\bar{\Xi} \\
\infty \\
\vec{\delta}-1 \\
\delta\end{array}$ & $\hat{n}$ & $\stackrel{m}{\circ}$ & $\stackrel{?}{\circ}$ & $\stackrel{\infty}{=}$ & ${ }_{\infty}^{\infty}$ & $\begin{array}{l}\infty \\
\dot{+}\end{array}$ & $\stackrel{\infty}{\stackrel{\circ}{+}}$ & $\bar{n}$ \\
\hline \multicolumn{2}{|c|}{ 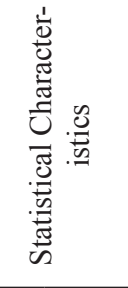 } & $\sum_{\bar{\Xi}}^{\Xi}$ & 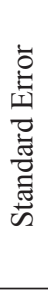 & 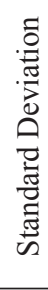 & 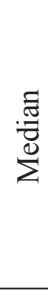 & 当 & 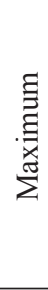 & 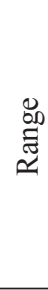 & 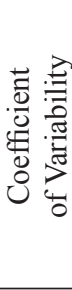 \\
\hline
\end{tabular}
The majority of cases describing daily mean 
Wasik E., et al.

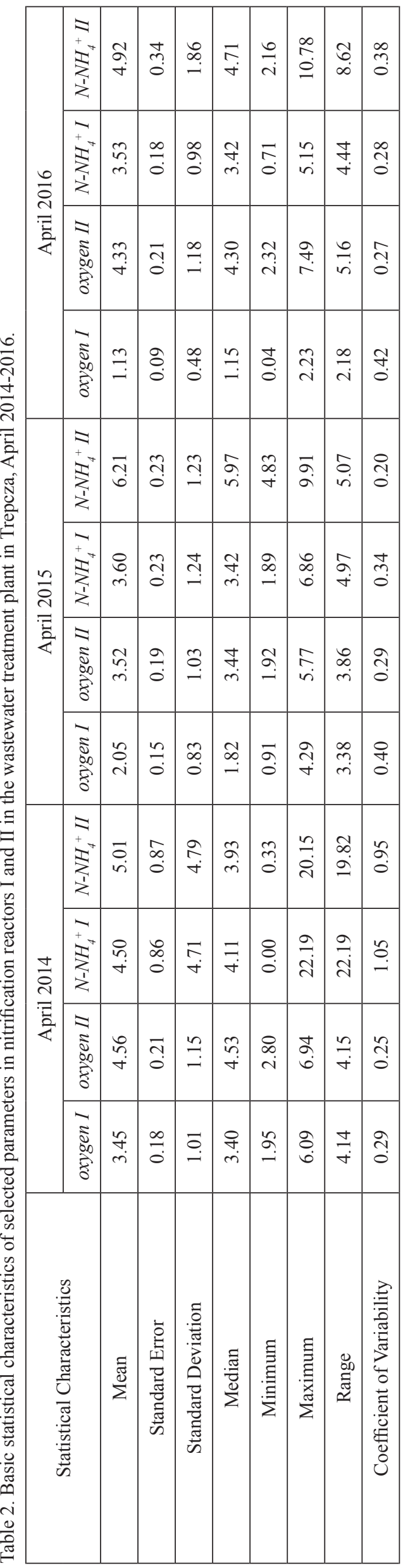

\begin{tabular}{|c|c|c|c|c|c|c|}
\hline \multirow{4}{*}{ 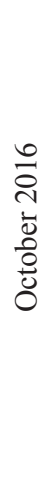 } & $\sum_{i=1}^{+\infty}=$ & $\stackrel{D}{D}$ & $\stackrel{\infty}{\check{\nu}}$ & 0 & $\because$ & $\begin{array}{l}\vec{\infty} \\
0\end{array}$ \\
\hline & $\sum_{i=1}^{+}-$ & $\stackrel{\mathscr{D}}{2}$ & $\stackrel{\mathscr{D}}{\beth}$ & $\simeq$ & $\begin{array}{l}\stackrel{0}{\mathrm{i}} \\
\text { in }\end{array}$ & $\stackrel{\text { g }}{-}$ \\
\hline & 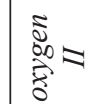 & ๑ & 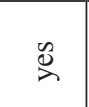 & 0 & $\star$ & $\frac{\circ}{9}$ \\
\hline & 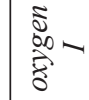 & 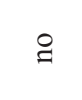 & 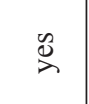 & 0 & $\star$ & $\stackrel{?}{\leftrightarrows}$ \\
\hline & $\sum_{i=1}^{+}=$ & $\stackrel{\mathscr{O}}{\beth}$ & $\stackrel{\mathscr{\nu}}{2}$ & $\stackrel{\infty}{\sim}$ & $\stackrel{\circ}{\circ}$ & $\begin{array}{l}n \\
0 \\
0\end{array}$ \\
\hline$\frac{n}{i}$ & $\sum_{1}^{+}-$ & 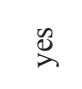 & $\stackrel{\mathscr{\nu}}{\check{\lambda}}$ & $\vec{\sim}$ & ț. & 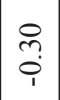 \\
\hline 递 & $\begin{array}{l}\bar{\Sigma} \\
\bar{\delta} \\
\bar{z} \\
0\end{array}$ & $\stackrel{9}{g}$ & $\stackrel{9}{g}$ & 0 & $\star$ & $\stackrel{n}{\leftrightarrow}$ \\
\hline & 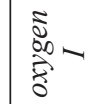 & $\stackrel{\mathscr{D}}{\lambda}$ & 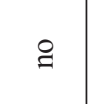 & 0 & $\star$ & : \\
\hline \multirow{4}{*}{ 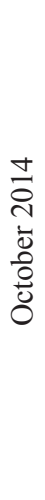 } & $\sum_{i}^{+}=$ & $\stackrel{D}{\partial}$ & $\stackrel{\infty}{2}$ & $a$ & $\hat{\mathrm{I}}$ & $\stackrel{0}{\stackrel{2}{\prime}}$ \\
\hline & $\sum_{\sum_{1}^{+}}^{+}-$ & $\stackrel{\infty}{\partial}$ & $\stackrel{\infty}{\check{\partial}}$ & 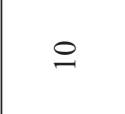 & $\begin{array}{l}0 \\
\stackrel{\sim}{\mathrm{N}}\end{array}$ & $\stackrel{\tilde{\sigma}}{\text { o }}$ \\
\hline & 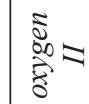 & g & g & $r$ & $\star$ & $\begin{array}{l}\text { in } \\
\text { in }\end{array}$ \\
\hline & 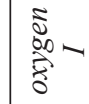 & 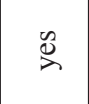 & g & I & $x$ & $\underset{+}{\vec{p}}$ \\
\hline \multirow{4}{*}{ 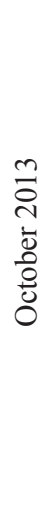 } & $\sum_{i}^{+}=$ & $\stackrel{\mathscr{D}}{\supset}$ & $\stackrel{D}{D}$ & $\hat{\sim}$ & $\frac{0}{\dot{n}}$ & के \\
\hline & $\sum_{\sum_{1}^{+}}^{+}-$ & 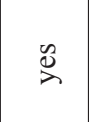 & $\stackrel{\check{D}}{D}$ & $\stackrel{\sim}{\sim}$ & 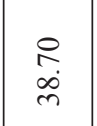 & $\frac{m}{0}$ \\
\hline & 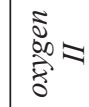 & g & g & 0 & $x$ & $\tilde{n}$ \\
\hline & 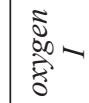 & 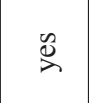 & g & - & $x$ & กิ \\
\hline \multicolumn{2}{|c|}{ 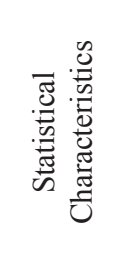 } & 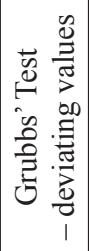 & 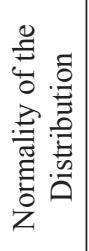 & 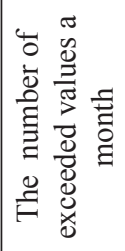 & 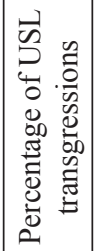 & $0^{\frac{3}{2}}$ \\
\hline
\end{tabular}




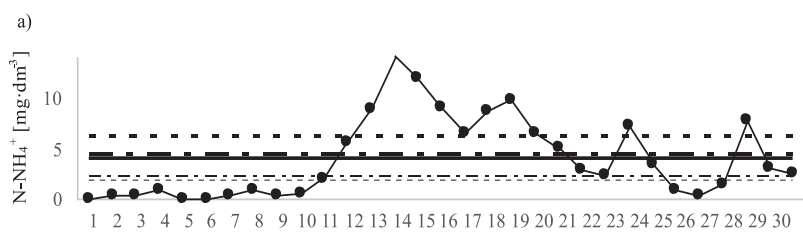

b)

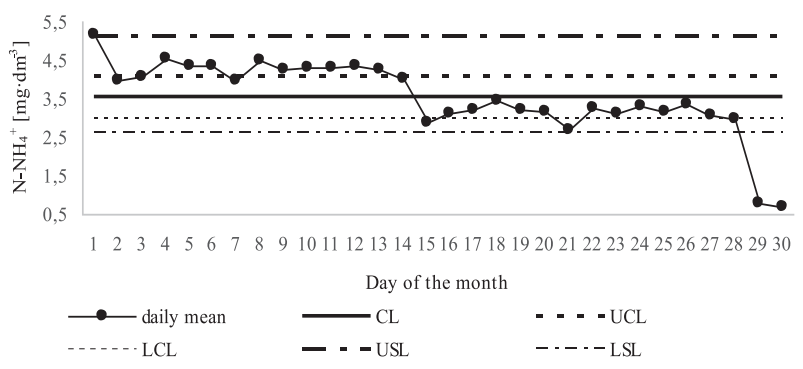

Fig. 2. Ammonium nitrogen control chart for reactor I: unstable process for October 2013 a), stable process for April 2016 b).

concentrations of dissolved oxygen did not follow the normal distribution. The obtained results with the results of Grubbs' test were put in Tables 3-4.

For daily means of the values of $\mathrm{N}^{-\mathrm{NH}_{4}+}$ concentration in both reactors, control charts were made and the index of the capacity of the process $\mathrm{C}_{\mathrm{pk}}$ was calculated (Tables 3 and 4). Based on this the nitrification process was assessed as stable if $\mathrm{C}_{\mathrm{pk}} \geq 1$, or unstable if $\mathrm{C}_{\mathrm{pk}}<1$. In reactor I a more stable nitrification process was obtained for the mean oxygen concentration 1.13-2.05 $\mathrm{mgO}_{2} \cdot \mathrm{dm}^{-3}$. The lowest mean concentrations of ammonia nitrogen were obtained in the range 3.43-3.62 $\mathrm{mgN}-\mathrm{NH}_{4}^{+} \cdot \mathrm{dm}^{-3}$. Reactor II worked at mean oxygen concentration $1.69-4.56 \mathrm{mgO} \cdot \mathrm{dm}^{-3}$, which caused lower stability in this study period. The mean concentration of ammonium nitrogen ranged from

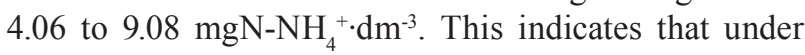
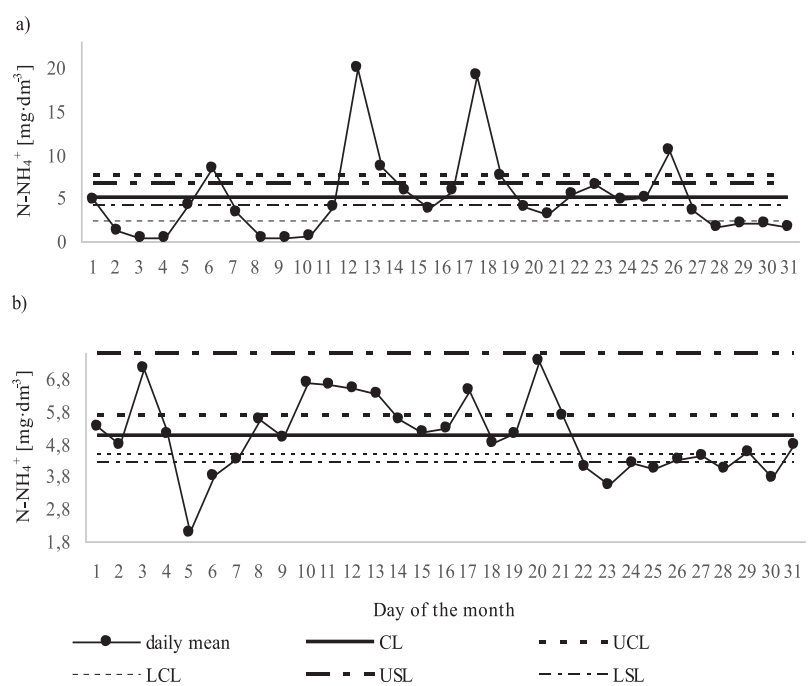

Fig. 3. Ammonium nitrogen control chart for reactor II: unstable process for April 2014 a), stable process for October 2016 b).

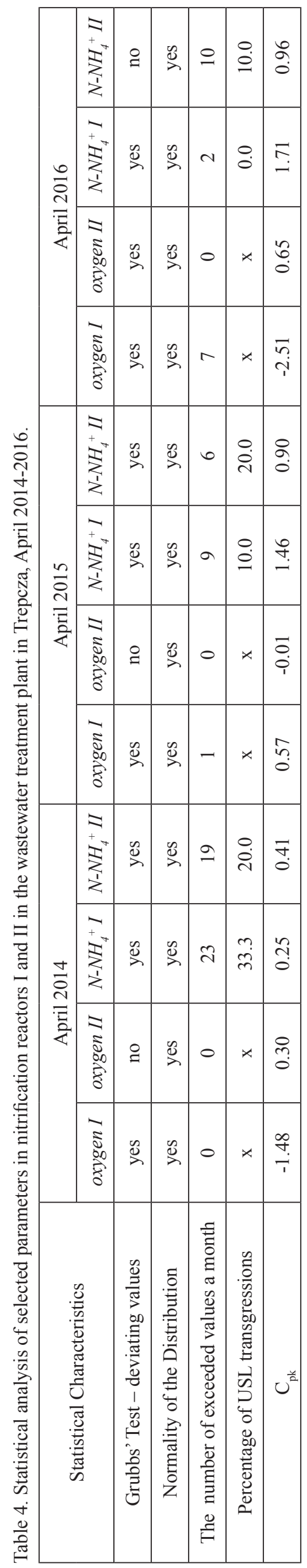


Table 5. Comparison of statistical characteristics in nitrification reactors I and II in the wastewater treatment plant in Trepcza, April and October over several years.

\begin{tabular}{|c|c|c|c|c|c|c|c|c|}
\hline \multirow{2}{*}{ Statistical Characteristics } & \multicolumn{4}{|c|}{ October $-2013 \div 2016$} & \multicolumn{4}{|c|}{ April $-2014 \div 2016$} \\
\hline & oxygen I & oxygen II & $\mathrm{N}-\mathrm{NH}_{4}^{+} \mathrm{I}$ & $\mathrm{N}-\mathrm{NH}_{4}^{+} \mathrm{II}$ & oxygen I & oxygen II & $\mathrm{N}-\mathrm{NH}_{4}^{+} \mathrm{I}$ & $\mathrm{N}-\mathrm{NH}_{4}^{+} \mathrm{II}$ \\
\hline Mean & 1.64 & 2.58 & 3.28 & 6.06 & 2.21 & 4.14 & 3.88 & 5.38 \\
\hline Standard Error & 0.12 & 0.20 & 0.34 & 0.51 & 0.14 & 0.20 & 0.42 & 0.48 \\
\hline Standard Deviation & 0.65 & 1.12 & 1.91 & 2.81 & 0.77 & 1.12 & 2.31 & 2.63 \\
\hline Median & 1.39 & 2.17 & 2.78 & 6.10 & 2.13 & 4.09 & 3.65 & 4.87 \\
\hline Minimum & 0.94 & 1.27 & 0.66 & 1.50 & 0.97 & 2.35 & 0.87 & 2.44 \\
\hline Maximum & 3.63 & 4.85 & 7.72 & 13.27 & 4.20 & 6.73 & 11.40 & 13.61 \\
\hline Range & 2.70 & 3.58 & 7.06 & 11.77 & 3.23 & 4.39 & 10.53 & 11.17 \\
\hline Variability Coefficient & 0.42 & 0.46 & 0.57 & 0.40 & 0.37 & 0.27 & 0.56 & 0.51 \\
\hline $\begin{array}{l}\text { The sum of transgressions / } \\
\text { month }\end{array}$ & 18 & 7 & 69 & 60 & 8 & 0 & 34 & 35 \\
\hline $\begin{array}{c}\text { Mean percentage } \\
\text { of transgressions USL }\end{array}$ & $\mathrm{x}$ & $\mathrm{x}$ & 22.6 & 16.1 & $\mathrm{x}$ & $\mathrm{x}$ & 14.4 & 16.7 \\
\hline
\end{tabular}

low $D O, A O B$ grew faster than $N O B$. This is confirmed by the dry matter content in reactor I than in reactor II [38]. Inhibition of $A O B$ growth was not observed due to the accumulation of toxic nitrites or by-products such as $\mathrm{NO}$ and $\mathrm{N}_{2} \mathrm{O}$.

The process of nitrification in both reactors was qualified as stable when oxygen concentration was between 1 to $2 \mathrm{mgO}_{2} \cdot \mathrm{dm}^{-3}$. In the 7 analyzed months, reactor I was characterized by more stable work (4 cases $\mathrm{C}_{\mathrm{pk}} \geq 1$ ) than in reactor II.

Graphs $2 \mathrm{a}$ and $3 \mathrm{a}$ give an example of control charts made for October 2013 and April 2014, when nitrification processes in both reactors I and II were found to be unstable.

This time both reactors were still at the stage of elaborating the technology. The annual period of their work from the modernization of wastewater treatment plant was characterized by a very large number of the incidents of exceeding the borders of specification 1927 times a month (Tables 3-4). Also, the percentage of exceeded USL was the highest and reached $52 \%$ in the case of reactor II. The indexes of process capacity $\mathrm{C}_{\mathrm{pk}}$ in the analysed period were on the level close to zero and did not exceed value 0.41 (Tables 3 and 4).

October 2014 is a period when the nitrification process in both reactors was considered stable. For this time interval mean concentration of ammonium nitrogen achieved the values $3.62 \mathrm{mgN}-\mathrm{NH}_{4}^{+} \cdot \mathrm{dm}^{-3}$ (in reactor I) and $6.04 \mathrm{mgN}-\mathrm{NH}_{4}^{+} \cdot \mathrm{dm}^{-3}$ (in reactor II) (Tables 1-2). Index of the capacity of the process $\mathrm{C}_{\mathrm{pk}}$ turned out to be high and was 1.03 and 1.76, respectively (Table 3 ).

The value of ammonium nitrogen concentration and the variability coefficients obtained in April 2015 were close to those in October 2014. Also, this period was characterized by high coefficient of the capacity of the process, which in the case of reactor I was 1.46 and indicated a stable process. In reactor II the calculated coefficient of the capacity of the process was on a low level $\left(\mathrm{C}_{\mathrm{pk}}=0.90\right)$ (Table 4).

The lowest mean values of ammonium nitrogen concentration in both reactors were in October 2015 (Table 1). Nevertheless, $65 \%$ of transgressions and negative values of index $\mathrm{C}_{\mathrm{pk}}$ (Table 3 ) indicate the lack of stabilization of the nitrification process in that month.

Figs 2b) and 3b) present a control chart made for April 2016, when the nitrification process in reactors I and II was considered the most stable of 7 investigated month intervals. No USL transgressions were noted in reactor I, while in reactor II their proportion was only $10 \% .2$ and 10 points a month, respectively, were outside the borders of specification. The index of the process capacity $\mathrm{C}_{\mathrm{pk}}$ turned out to be the highest in this study period, and for reactor I reached the very high value of 1.71 (Table 4).

In October 2016 the nitrification process in reactor I was qualified as stable, despite the fact that 12 points were outside the borders of specification, a percentage of USL transgressions was $22.6 \%$ (Table 3 ). The index of process $\mathrm{C}_{\mathrm{pk}}$ in this period turned out to be very high and reached 1.49. In reactor I mean concentration of ammonium nitrogen obtained the value of $3.43 \mathrm{mgN}$ $\mathrm{NH}_{4}^{+} \cdot \mathrm{dm}^{-3}$. Reactor II was characterized by a lack of points beyond USL, which was visualized in a control chart (Fig. 3b).

Also of low value were the variability coefficient and the index of the process capacity $\mathrm{C}_{\mathrm{pk}}$ equalling 0.81 (Table 3), indicating that at that time the nitrification process turned out to be quite stable.

Comparing the parameters of work of the reactors in both months in the period of many years (Table 5 ), one can state that the nitrification reactors were 
characterized by a smaller range and standard deviation of the oxygen concentration in October, and smaller variability coefficient and the number of oxygen exceeding in April. This was reflected in the low number of transgressions and mean percentages of USL transgressions for ammonium nitrogen. This means that in this period more favourable thermal conditions are necessary to make nitrification possible. Kaczor [43] observed lower reduced work of the open activated sludge reactor in a municipal sewage treatment plant in Koszyce, when temperature was below $12^{\circ} \mathrm{C}$ (from November to April). Wasik et al. [44] noted 37 cases of exceedance of the permitted reduction of total nitrogen for the wastewater treatment plant in Krosno when temperature dropped below $10^{\circ} \mathrm{C}$ (from December to mid-April). Maciołek et al. [45] observed the inhibition of the nitrification process in the Koszalin treatment plant at a temperature less than $10^{\circ} \mathrm{C}$.

In the studied wastewater treatment plant the process of nitrification was more stable in April. The mean number of transgressions in that month in 2014-2016 for both reactors was lower than the mean number of transgressions in October in 2013-2016. Analyzing mean percentage of exceeding the upper limit of specification (USL), it was stated that in reactor I the process was more stabilized in April (14.4\% of unstable fraction), while reactor II worked with similar stability both in April, as well in October (16.1-16.7\% of unstable fraction). For the latter, the mean concentration of ammonium nitrogen in reactor II was characterized by the highest value $6.06 \mathrm{mgN}-\mathrm{NH}_{4}^{+} \cdot \mathrm{dm}^{-3}$. The lowest mean value of ammonium nitrogen in reactor I equalling $3.28 \mathrm{mgN}-\mathrm{NH}_{4}^{+} \cdot \mathrm{dm}^{-3}$ was recorded in October. Akarupu et al. [28] for data for the months of January, April, May, July, September, October, and November observed only two data points above UCL, but below the permitted monthly average limit for ammonia of $4.0 \mathrm{mgN}-\mathrm{NH}_{4}^{+} \cdot \mathrm{dm}^{-3}$.

\section{Conclusions}

Based on our analysis the following conclusions can be drawn:

1) After a 2013 modernization of the wastewater treatment plant, the process of nitrification was a more stable in reactor I. This indicates the analysis obtained within 7 months of higher values of the index of process capacity $\mathrm{C}_{\mathrm{pk}}$ and lower mean value of ammonium nitrogen concentration than in reactor II.

2) The analysis of control charts showed that the highest instability of the nitrification process in both reactors was when the plant modernization took place (October 2013 and April 2014). It was also characterised by the highest coefficients of variability $\mathrm{N}-\mathrm{NH}_{4}^{+}$.

3) The most stable, among 7 examined months, was April 2016. In this period, no exceeded USL values in reactor I were recorded, while in reactor II their number was only $10 \%$. Stability of nitrification is confirmed by the highest index of the process capacity $\mathrm{C}_{\mathrm{pk}}$, which for reactor I achieved a value of 1.71. Index $\mathrm{C}_{\mathrm{pk}}$ for reactor II was also high at 0.96 .

4) In the last month of the analyses in October 2016, the nitrification process in reactors I and II was qualified as stable. Thus it can be stated that after the longer time of the functioning of wastewater treatment plant, after its modernization, the nitrification processes were more stable.

5) The process of nitrification in both reactors was qualified as stable when oxygen concentration was between 1 to $2 \mathrm{mgO}_{2} \cdot \mathrm{dm}^{-3}$. In reactor I a more stable nitrification process was obtained for the mean oxygen concentration 1.13-2.05 $\mathrm{mgO}_{2} \cdot \mathrm{dm}^{-3}$. Reactor II worked at mean oxygen concentration 1.69-4.56 $\mathrm{mgO}_{2} \cdot \mathrm{dm}^{-3}$, which caused lower stability in the study period.

6) The presented techniques of statistic control of the process, which are based on PCA and control charts, showed their usefulness in the monitoring of the nitrification process in the wastewater treatment plant working for Sanok agglomeration.

\section{References}

1. VAN HAANDEL A.C., VAN DER LUBBE J.G.M. Handbook of biological wastewater treatment: design and optimisation of activated sludge system; IWA Publishing, 2012.

2. BAGCHI S., BISWAS R., NANDY T. Autotrophic Ammonia Removal Processes: Ecology to Technology. Critical Reviews in Environmental Science and Technology, 42, 1353, 2012.

3. HENZE M., VAN LOOSDRECHT M.C.M., EKAMA G.A., BRDJANOVIC D. Biological Wastewater Treatment - Principles, Modelling and Design, IWA Publishing 2008.

4. ZENG W., BAI X., ZHANG L., WANG A., PENG Y. Population dynamics of nitrifying bacteria for nitritation achieved in Johannesburg (JHB) process treating municipal wastewater, Bioresource Technology, 162, 30, 2014.

5. VANNECKE T.P.W., BERNET N., STEYER J.-P., VOLCKE E.I.P. Modelling ammonium-oxidizing population shifts in a biofilm reaktor, Water Science \& Technology, 69 (1), 208, 2014, DOI: 10.2166/wst.2013.701

6. VOLCKE E.I.P, SANCHEZ O., STEYER J.-P., DABERT P., BERNET N. Microbial population dynamics in nitrifying reactors: Experimental evidence explained by a simple model including interspecies competition, Process Biochemistry, 43, 1398, 2008.

7. ABBAS G., ZHENG P., WANG L., LI W., ZHANG M., ZHANG J. Oxygen Transfer Characteristics in a PilotScale Airlift Internal-Loop Bioreactor for Simultaneous Partial Nitrification and Anaerobic Ammonia Oxidation, Environmental Engineering Science 31 (8), 453, 2014, DOI: 10.1089/ees.2013.0453

8. HU B., TIAN X., ZHAO J., WU P., YANG W., CHEN Y. Theoretical Analysis of Microbial Yield and Pathways Related to N2O Production in Nitrification, Pol. J. Environ. Stud., 26 (1), 79-85, 2017, DOI: 10.15244/pjoes/64376

9. AWWA STAFF. Fundamentals and Control of Nitrification in Chloraminated Drinking Water Distribution Systems, 2006. 
10. TCHOBANOGLOUS G., BURTON F.L., STENSEL H.D. Wastewater Engineering. Treatment and Reuse. Metcalf \& Eddy, Inc., $4^{\text {th }}$ ed.; McGraw-Hill, Inc.: New York, 2003.

11. BARTOSZEWSKI K., BICZ W., DYMACZEWSKI Z., JAROSZYŃSKI T., KUJAWA K., LEMAŃSKI J., ŁOMOTOWSKI J., NALBERCZYŃSKI A., NIEDZIELSKI W., OLESZKIEWICZ J., SAWICKI M., SOZAŃSKI M., URBANIAK A., WASILEWSKI M. Poradnik eksploatatora oczyszczalni ścieków (Operator's manual of sewage treatment plant); PZiTS: Poznań, 2011 [In Polish].

12. BOX G.E.P., JENKINS G.M. Analiza szeregów czasowych. Prognozowanie i sterowanie (Analysis of time series. Forecasting and control); PWN: Warszawa, 1983 [In Polish].

13. SHEWHART W.A. Economic Control of Quality of Manufactured Products. Van Nostrand, New York; Reprint: American Society for quality control: Milwaukee, WI, 1981

14. ISO 7870-1:2014. Control charts - General guide and introduction.

15. ISO 7870-2:2013. Control charts - Shewhart control charts.

16. STATSOFT, Online Statistics Handbook. Available online: http://www.statsoft.pl/textbook/ stathome.html (accessed: 30.07.2017).

17. GREBER T. Control charts for numerical evaluation in process control - assumptions and analysis, Statsoft, Kraków, Available online: http://www.statsoft.pl/ Czytelnia/Jakosc-SPC/ (accessed: 30.06.2017).

18. KORONACKI J. Methods of statistical quality control. Available online: http://www.statsoft.pl/Czytelnia/JakoscSPC/ (accessed: 30.07.2017).

19. HAMROL A. Zarzq̨dzanie jakościq z przykładami (Quality management with examples). PWN, Warszawa, 2005 [In Polish].

20. OLSSON G. Process control. Chapter 10 in Hartley, Ken: Tuning Biological Nutrient Removal Plants; IWA Publishing: London, 2013.

21. GEORGE JP., CHEN Z., SHAW P. Fault Detection of Drinking Water Treatment Process Using PCA and Hotelling's T2 Chart. World Academy of Science, Eng and Technol, 26, 970, 2009.

22. MANOJ K., PADHY PK. Multivariate statistical techniques and water quality assessment: Discourse and review on some analytical models. Internl $\mathrm{J}$ of Environ Sciences, 5 (3), 607, 2014.

23. MUSTAPHA A., ARIS A.Z. Multivariate Statistical Analysis and Environmental Modeling of Heavy Metals Pollution by Industries, Pol. J. Environ. Stud., 21 (5), 1359, 2012.

24. ÖZDEMIR Ö. Application of Multivariate Statistical Methods for Water Quality Assessment of KarasuSarmisakli Creeks and Kizilirmak River in Kayseri, Turkey, Pol. J. Environ. Stud., 25 (3), 1149, 2016, DOI: $10.15244 /$ pjoes $/ 61850$

25. VENKATRAMANAN S., CHUNG SY., LEE SY., P ARK N. Assessment of river water quality via environmentric multivariate statistical tools and water quality index: a case study of Nakdong River Basin, Korea, Carpathian Journal of Earth and Environmental Sciences, 9 (2), 125, 2014.

26. YANG Q., ZHANG J., WANG Y., FANG Y., MARTÍN J.D. Multivariate Statistical Analysis of Hydrochemical Data for Shallow Ground Water Quality Factor Identification in a Coastal Aquifer, Pol. J. Environ. Stud., 24 (2), 769, 2015, DOI: $10.15244 /$ pjoes/30263
27. AKARUPU V., GUNKALA S., PATTIGADAPA S. PATTIGADAPPA B.K., PONNAPALLI S., SEGALL R.S. Statistical Quality Control and Improvement of Waste Water Treatment Plant, Proceedings of The $20^{\text {th }}$ World Multi-Conference on Systemics, Cybernet and Informatics, 2016.

28. MEES JBR., GOMES SD., VILAS BOAS MA., GOMES BM., PASSIG FH. Kinetic behavior of nitrification in the post-treatment of poultry wastewater in a sequential batch reactor. Eng Agríc, Jaboticabal, 31 (5), 954, 2011.

29. NUGRAHA J., FATIMAH I., PRABOWO R.G. Control of wastewater using multivariate control chart, AIP Conference Proceedings 1823, 020126; Published by the American Institute of Physics, 2017, doi: 10.1063/1.4978199

30. ROJAS J.D., FLORES-ALSINA X., JEPPSSON U., VILANOVA R. Application of multivariate virtual reference feedback tuning for wastewater treatment plant control. Control EngPractice, 20, 499, 2012.

31. TECHNICAL GUIDANCE NOTE (Monitoring), M18: Monitoring of discharges to water and sewer, Environment Agency Version 4 November 2014.

32. WAŁEGA A., KRZANOWSKI S. Utiliziation of the reliability theory and statistical quality control to assess the operation of rural sewage treatment plants. Infrastructure and Ecology of Rural Areas, 3 (2), 17, 2006.

33. GARCIA-ALVAREZ D., FUENTE M.J., VEGA P., SAINZ G. Fault Detection and Diagnosis using Multivariate Statistical Techniques in a Wastewater Treatment Plant. In: $7^{\text {th }}$ IFAC International Symposium on Advanced Control of Chemical Process, Turkey, 2009.

34. JANIAK K., BALBIERZ P., KNAP M. Control charts as a tool of measurement errors search. Available online: www. eko-dok.pl/2012/25.pdf, 2012 (accessed 30.06.2017).

35. AKPOŚK, Available online: http://www.kzgw.gov.pl/pl/ Krajowy-program-oczyszczania-sciekowkomunalnych. html (accessed: 30.06.2010).

36. WAૃSIK E., CHMIELOWSKI K. Ocena sprawności oczyszczania ścieków w oczyszczalni dla miasta i gminy Sanok w świetle zmian wybranych czynników klimatu (Evaluation of sewage treatment plant efficiency for the city of Sanok in light of changes selected climate factors). Gas Water and Sanitary Technology, LXXXVI (2), 103, 2012 [in Polish].

37. SPGK SANOK, http://jrp.spgk.com.pl/realizacja-projektu (accessed: 07.2013).

38. WA¿SIK E., CHMIELOWSKI K., OPERACZ A. PCA jako narzędzie eksploracji danych charakteryzujących pracę komór nitryfikacji oczyszczalni ścieków w Trepczy (PCA as a data mining tools characterizing the work of nitrification reactors in the sewage treatment plant in Trepcza). Acta Scientiarum Polonorum, Formatio Circumiectus, 16 (1), 209, 2017 [In Polish].

39. CLIMATE, Available online: https://pl.climate-data.org (accessed: 01.08.2017).

40. TUTIEMPO.NET, Available online: https://en.tutiempo.net (accessed: 01.08.2017).

41. WOŹNIAK A. Opady w 2010 roku w Karpatach Polskich na tle wielolecia 1881 - 2010 (Rainfall in 2010 in the Polish Carpathians on the background of 1881-2010). Prace Geograficzne, 133, 35, 2013 [In Polish].

42. WALANUS A. Zdolność procesu. Available online: http://www.statsoft.pl/Czytelnia/Jakosc-SPC/ (accessed: 30.07.2017)

43. KACZOR G. Wpływ temperatury powietrza na temperaturę ścieków w kanalizacji i reaktorze biologicznym (Air 
temperature influence on sewage temperature in sewer and biological reactor). Infrastructure and Ecology of Rural Areas, 3, 129, 2008 [In Polish].

44. WĄSIK E., LUUBOS̆ J., CHMIELOWSKI K., OPERACZ A., BUGAJSKI P. Statistical Process Control of nitrogen compounds removal in the sewage treatment plant in
Krosno, Infrastructure and Ecology of Rural Areas, 2017 [In press].

45. MACIOŁEK P., JANOWSKA B., SZYMAŃSKI K. Removal of Nitrogen from Municipal Wastewater Using an External Carbon Source. Annual Set The Environ Protec, 18, 885, 2016. 